\title{
HUBUNGAN DUKUNGAN KELUARGA DAN PENGETAHUAN TERHADAP PERAWATAN DIRI PENDERITA KUSTA DI PUSKESMAS GRATI TAHUN 2016
}

\author{
Alif Farkhanan Nur Laili \\ Departemen Epidemiologi Fakultas Kesehatan Masyarakat \\ Universitas Airlangga Surabaya, Jawa Timur, Indonesia \\ Alamat Korespondensi: \\ Alif Farkhanan Nur Laili \\ Email: aliffarkhanannurlaili@gmail.com
}

\begin{abstract}
Indonesia is the country with the third highest number of leprosy with 16131 patients in 2014 in disability prevalence rate of 6,82 per 1 million inhabitants (MoH RI,2014). East Java is the province with the most cases of leprosy in Indonesia (Ministry of Health, 2014). Pasuruan is one of the areas with high leprosy burden with the number of cases reached 175 cases and $16.57 \%$ of them have disabilities level 2 (DHO Pasuruan, 2015). Prevention of disability can be done with self-care measures. Factors that support the successful self-care of leprosy patients including the support of family and knowledge of leprosy patients. The purpose of this study to determine the relationship between family support and knowledge with self-care of lepers. This study using cross sectional study design. The sampling technique using simple random sampling and obtained a sample of 46 people. Data were collected by interview. Data analysis using Pearson correlation test. Showed no relationship between family support with self-care of leprosy patients with $p$ value of $0.00<0.5$ with correlation coefficient 0.690 . There is a relationship between knowledge and self-care with a $0.00 \mathrm{p}$ value $<0.05$ with correlation coefficient 0.691. The need for an optimization program based self-care group families to improve family support, especially in terms of information support.
\end{abstract}

Keywords: self-care of leprosy, family support, knowledge

\begin{abstract}
ABSTRAK
Indonesia merupakan negara dengan peringkat ketiga terbanyak penderita kusta. Tahun 2014 prevalensi kusta mencapai 16.131 dengan angka prevalensi kecacatan sebesar 6,82 per 1.000 .000 penduduk (Kemenkes RI, 2014). Jawa Timur merupakan provinsi dengan kasus terbanyak kusta di Indonesia (Kemenkes,2014). Kabupaten Pasuruan merupakan salah satu daerah dengan beban kusta tinggi dengan jumlah kasus mencapai 175 kasus dan 16,57\% diantaranya mengalami kecacatan tingkat 2 (Dinkes Kabupaten Pasuruan, 2015). Upaya pencegahan kecacatan bisa dilakukan dengan tindakan perawatan diri. Faktor yang menunjang keberhasilan perawatan diri penderita kusta diantaranya adalah dukungan dari keluarga dan pengetahuan penderita kusta. Tujuan penelitian ini untuk mengetahui hubungan antara dukungan keluarga dan pengetahuan dengan perawatan diri penderita kusta. Penelitian ini menggunakan disain study cross sectional. Teknik pengambilan sampel menggunakan simple random sampling dan diperoleh sampel sebesar 46 orang. Pengambilan data dilakukan dengan wawancara. Analisis data menggunakan uji korelasi Pearson. Didapatkan hasil ada hubungan antara dukungan keluarga dengan perawatan diri penderita kusta dengan $p$ value sebesar $0,00<0,5$ dengan nilai koefisien korelasi 0,690. Terdapat hubungan antara pengetahuan dengan perawatan diri dengan $p$ value $0,00<0,05$ dengan nilai koefisien korelasi 0,691 . Perlu adanya pengoptimalan program kelompok perawatan diri berbasis keluarga untuk meningkatkan dukungan keluarga terutama pada aspek dukungan informasi.
\end{abstract}

Kata kunci: perawatan diri kusta, dukungan keluarga, pengetahuan 


\section{PENDAHULUAN}

Kusta atau disebut juga Morbus Hansen merupakan penyakit yang menyerang kulit maupun saraf yang disebabkan oleh infeksi microbacterium leprae. Kusta berasal dari bahasa sansekerta yaitu Kusta yang artinya kumpulan gejala penyakit kulit secara umum (Kemenkes RI, 2015). Kusta yang tidak memperoleh penanganan secara tepat dan tidak terdeteksi akan secara progresif menyerang kulit, saraf anggota gerak dan mata yang selanjutnya akan menimbulkan kecacatan.

Kecacatan yang dialami oleh penderita kusta menyebabkan berbagai macam dampak sosial maupun psikologis. Dampak sosial yang dialami diantaranya adalah penderita tidak dapat melakukan fungsi sosial dalam masyarakat, terisolasi dari pergaulan dalam keluarga maupun masyarakat sekitar serta dalam segi psikologis akan menurunkan harga diri penderita akibat kecacatan yang ditimbulkan. (Soedarjatmi, dkk, 2009)

Menurut WHO (2016), angka penemuan kasus baru kusta diseluruh dunia mulai tahun 2011 hingga 2015 mengalami penurunan yang tidak signifikan. Pada tahun tersebut ditemukan 226.626 kasus pada tahun 2011, 232.857 pada tahun 2012, 215.656 kasus pada tahun 2013, 213.899 kasus pada tahun 2014 dan 201.758 pada tahun 2015. Asia Tenggara merupakan regional dengan jumlah penderita kusta terbanyak di dunia pada tahun 2015 dengan angka kejadian sebesar 156.118 kasus dan 14.059 per 1.000 .000 mengalami kecacatan tingkat 2 di mana penderita mengalami kelainan anatomis.

Jumlah penemuan kasus baru kusta di Indonesia pada tahun 2010 mencapai 17.012 kasus, meningkat pada tahun 2011 menjadi 20.023 kasus. Tahun 2012 menurun menjadi 18.994 kasus dan terus menurun pada tahun 2013 menjadi 16.856. Tahun 2014 jumlah kasus baru kusta kembali meningkat menjadi 17.025 kasus dan terus meningkat pada tahun 2015 menjadi 17.202 kasus dengan angka kecacatan tipe 2 mencapai 1.687 per 1.000.000 penduduk (WHO,2016). Angka penemuan kasus baru kusta di Indonesia memang mengalami penurunan, namun penurunan yang terjadi belum signifikan dan dari tahun ketahun masih ditemukan kasus baru.

Menurut Kemenkes Republik Indonesia (2014) terdapat 14 provinsi $(42,4 \%)$ termasuk dalam beban kusta tinggi, salah satu diantaranya adalah Provinsi Jawa Timur dengan Crude Death Rate (CDR) 10,68 yang artinya pada 100.000 penduduk terdapat lebih dari 10 orang penderita kusta. Angka ini melibihi target pemerintah yang hanya 10 per 100.000 penduduk. Kabupaten Pasuruan merupakan salah satu daerah dengan angka kasus kusta tinggi di Jawa Timur dengan jumlah kasus mencapai 175 kasus dan 16,57\% diantaranya mengalami kecacatan tingkat 2 . Angka ini jauh melebihi target kecacatan yang ditetapkan pemerintah yaitu hanya 5\% (Dinkes Kabupaten Pasuruan, 2015).

Grati merupakan salah satu wilayah di Kabupaten Pasuruan dengan angka kusta tertinggi kedua di Kabupaten Pasuruan dengan prevalensi sebesar 5,56 per 10.000 penduduk (Dinas Kesehatan Kabupaten Pasuruan, 2016). Prevalensi tersebut masih jauh diatas target yang ditetapkan oleh pemerintah yaitu sebesar 1 per 10.000 penduduk. Jumlah penderita kusta yang tercatan di puskesmas grati mulai tahun 2014-2015 yaitu sebanyak 74 orang dan 10 atau $13,5 \%$ diantaranya mengalami kecacatan tingkat 2. Angka ini melebihi target pemerintah yang hanya $5 \%$.

Tingginya angka kecacatan serta dampak yang ditimbulkan oleh kecacatan maka perlu adanya upaya pencegahan yang adekuat. Upaya pencegahan tidak cukup hanya dengan pengobatan Multi Drug Theraphy (MTD) saja karena pengobatan hanya dapat membunuh kuman kusta, namun kecacatan yang dialami oleh penderita kusta akan terus ada seumur hidup. Upaya yang dapat dilakukan untuk pencegahan bertambah parahnya kecacatan yang diderita oleh penderita kusta yaitu dengan melakukan perawatan diri (Depkes, 2012). Hal ini 
sejalan dengan penelitian yang dilakukan oleh Santoso pada tahun 2006 di Kabupaten Sukoharjo Jawa Tengah yang menyatakan bahwa kecacatan pada penderita kusta dapat dipengaruhi oleh beberapa hal diantaranya adalah usia, lama mengidap penyakit kusta, ketaatan dalam berobat serta perawatan diri pasien kusta.

Keberhasilan perawatan diri yang dilakukan oleh penderita kusta dapat dipengaruhi oleh beberapa hal diantaranya adalah dukungan dari keluarga serta pengetahuan penderita kusta. Salah satu faktor pendukung keberhasilan penderita kusta yaitu dukungan dari keluarga penderita kusta. Menurut Friedman (2010), dukungan keluarga menjadi faktor penting dalam proses penyembuhan seseorang, keluarga dapat memberikan dorongan baik dari segi fisik maupun psikologis bagi penderita. Dukungan dari keluarga berdampak pada kecepatan penyembuhan seseorang serta meningkatkan fungsi kognitif maupun emosi seseorang (Setiadi, 2008). Ketika penderita kusta mendapatkan dukungan yang cukup maka penyembuhan akan semakin cepat, serta akan lebih giat dalam mencari dan melakukan upaya-upaya penyembuhan bagi dirinya dalam hal ini adalah upaya pencegahan cacat dengan melakukan perawatan diri. Hal ini sejalan dengan penelitian yang dilakukan Mahanani (2013), di Puskesmas Kunduran Kecamatan Kunduran Kabupaten Blora. Penelitian tersebut mendapatkan hasil bahwa ada hubungan antara dukungan keluarga dengan perawatan diri penderita kusta.

Faktor lain yang berperan dalam perawatan diri penderita kusta adalah dari aspek pengetahuan penderita kusta. Pengetahuan adalah hasil tahu manusia terhadap suatu objek melalui pengindraan yang dimiliki oleh manusia (Notoatmodjo, 2012). Menurut Blum (1974) pengetahuan adalah domain penting yang memengaruhi kesehatan individu. Semakin baik pengetahuan seseorang akan suatu permasalahan kesehatan maka semakin baik pula upaya peningkatan kesehatan yang dilakukan oleh seseorang. Begitupula pada permasalahan tentang kusta, semakin banyak informasi yang didapat akan semakin baik pengetahuan penderita kusta dalam hal ini adalah perawatan diri dalam upaya pencegahan kecacatan. Hal ini sejalan dengan penelitian yang dilakukan oleh Solikhah (2016) yang menunjukkan hasil bahwa terdapat hubungan yang signifikan antara tingkat pengetahuan dengan perawatan diri penderita kusta.

Melihat pentingnya upaya pencegahan kecacatan melalui tindakan perawatan diri maka peneliti tertarik untuk melakukan penelitian mengenai hubungan antara keikutsertaan kelompok perawatan diri (KPD), dukungan keluarga dan pengetahuan dengan perawatan diri pasien Kusta di Wilayah Kerja Puskesmas Grati Kabupaten Pasuruan tahun 2016. Penelitian ini bertujuan untuk menggambarkan karakteristik penderita kusta, menganalisis hubungan dukungan keluarga dan pengetahuan dengan perawatan diri penderita kusta.

\section{METODE PENELITIAN}

Penelitian ini adalah penelitian analitik dengan disain studi cross sectional. Penelitian ini dilakukan di wilayah kerja Puskesmas Grati, Kecamatan Grati Kabupaten Pasuruan pada bulan Desember 2016. Populasi dalam penelitian ini adalah seluruh penderita kusta yang tercatat pada register di Puskesmas Grati pada tahun 2014 hingga 2016 yang masih memerlukan perawatan diri yaitu sebanyak 52 orang.

Besar sampel dalam populasi ini dihitung dengan menggunakan rumus Lameshow (1997), dan didapatkan sampel sebesar 46 orang. Teknik pengambilan sampel menggunakan simple random sampling. Langkah pertama pengambilan sampel yaitu mendaftar nama seluruh populasi yang telah ditetapkan yaitu sebanyak 52 orang. Selanjutnya membuat tabel random untuk menentukan sampel, dari tabel random tersebut didapatkan sampel yang dibutuhkan sesuai perhitungan yang dilakukan yaitu sebanyak 46 orang. 
Tabel 1. Distribusi Responden Berdasarkan Karakteristik di Wilayah Kerja Puskesmas Grati Tahun 2016

\begin{tabular}{|c|c|c|}
\hline $\begin{array}{c}\text { Karakteristik } \\
\text { Responden }\end{array}$ & Jumlah & $\%$ \\
\hline \multicolumn{3}{|l|}{ Umur } \\
\hline 17-25 tahun & 4 & 8,7 \\
\hline 26-35 tahun & 3 & 6,5 \\
\hline 36-45 tahun & 6 & 13 \\
\hline 46-55 tahun & 16 & 34,8 \\
\hline 56-65 tahun & 12 & 26,1 \\
\hline$>65$ tahun & 5 & 10,9 \\
\hline Total & 46 & 100 \\
\hline \multicolumn{3}{|l|}{ Jenis Kelamin } \\
\hline Laki-laki & 25 & 54,3 \\
\hline Perempuan & 21 & 45,7 \\
\hline Total & 46 & 100 \\
\hline \multicolumn{3}{|l|}{ Pendidikan } \\
\hline PT/AKADEMI & 0 & 0 \\
\hline SMA & 2 & 4,3 \\
\hline SMP & 1 & 2,2 \\
\hline $\mathrm{SD}$ & 14 & 30,4 \\
\hline Tidak Sekolah & 29 & 63 \\
\hline Total & 46 & 100 \\
\hline \multicolumn{3}{|l|}{ Pekerjaan } \\
\hline PNS/TNI/POLRI & 0 & 0 \\
\hline Wiraswasta & 4 & 8,7 \\
\hline Swasta & 5 & 10,9 \\
\hline Buruh tani & 22 & 47,8 \\
\hline Tidak Bekerja & 15 & 32,6 \\
\hline Total & 46 & 100 \\
\hline \multicolumn{3}{|l|}{ Pendapatan } \\
\hline$\geq \mathrm{UMR}$ & 1 & 2,2 \\
\hline$<\mathrm{UMR}$ & 45 & 97,8 \\
\hline Total & 46 & 100 \\
\hline \multicolumn{3}{|l|}{ Jenis Kusta } \\
\hline Pausi Basiler & 3 & 6,5 \\
\hline Multi Basiler & 43 & 93,5 \\
\hline Total & 46 & 100 \\
\hline
\end{tabular}

\begin{tabular}{lrc}
\hline \multicolumn{1}{c}{$\begin{array}{c}\text { Karakteristik } \\
\text { Responden }\end{array}$} & Jumlah & \% \\
\hline Kepemilikan BPJS & & \\
Punya,digunakan & 32 & 69,6 \\
Punya,tidak digunakan & 2 & 4,3 \\
Tidak Punya & 12 & 26,1 \\
\hline Total & 46 & 100 \\
\hline Keikutsertaan KPD & & \\
Ikut & 21 & 45,6 \\
Tidak ikut & 25 & 54,4 \\
\hline Total & 46 & 100 \\
\hline
\end{tabular}

Variabel tergantung dalam penelitian ini adalah perawatan diri penderita kusta. Variabel bebas dalam penelitian ini adalah dukungan keluarga serta pengetahuan penderita kusta.

Data yang digunakan dalam penelitian ini seluruhnya menggunakan data primer yang diambil dengan metode wawancara dengan panduan kuesioner yang dilakukan secara door to door. Kuesioner terdiri dari 5 kelompok pertanyaan yaitu mengenai karakteristik atau data umum responden, akses pelayanan kesehatan, dukungan keluarga yang terdiri dari 4 komponen dukungan yaitu dukungan pengharapan, dukungan nyata, dukungan informasi dan dukungan emosional, pertanyaan terakhir mengenai perawatan diri penderita kusta.

Masing-masing pertanyaan diberi bobot nilai yang kemudian total skor dikategorikan. Data yang telah diperoleh diolah menggunakan program Ecxel dan SPSS dan disajikan dalam bentuk tabel dan narasi. Analisis data yang dilakukan terdiri dari dua analisis yaitu analisis univariate untuk mengetahui distribusi frekwensi karakteristik responden, akses pelayanan kesehatan, dukungan keluarga dan pengetahuan. Analisi yang kedua yaitu analisis bivariate menggunakan uji korelasi 
pearson untuk mengetahui hubungan antara variable bebas dan tergantung.

\section{HASIL}

Penelitian yang dilakukan selama dua minggu ini menghasilkan informasi mengenai beberapa variabel, diantaranya adalah karakteristik responden (umur, jenis kelamin, pendidikan, pekerjaan, pendapatan, jenis kusta, kepemilikan BPJS dan keikutsertaan dalam kelompok perawatan diri), dukungan keluarga, pengetahuan responden serta tindakan perawatan diri responden.

Usia responden dikelompokkan menjadi 6 kategori berdasarkan klasifikasi Depkes RI tahun 2009 yaitu kelompok remaja akhir di mana rentang usia 17-25 tahun, dewasa awal dengan rentang usia 26-35 tahun, dewasa akhir dengan rentang usia 36-45 tahun, lansia awal dengan rentang usia 46-55 tahun, lansia akhir dengan rentang usia 56-65 tahun dan manula yaitu usia diatas 65 tahun.

\section{Karakteristik responden}

Berdasarkan hasil penelitian didapatkan bahwa responden terbanyak berada pada rentang usia 46-55 tahun, usia ini masuk dalam kelompok usia lansia awal dengan persentase $34,8 \%$. Jenis kelamin responden terbanyak adalah laki-laki, namun jumlah ini tidak berbeda secara signifikan dengan jenis kelamin perempuan.

Sebagian besar responden dalam segi pendidikan tidak pernah mengenyam pendidikan formal persentasenya mencapai $63 \%$. Responden yang menyelesaikan wajib belajar 12 tahun atau sampai SMA hanya 2 orang atau $4,3 \%$ dari total keseluruhan. Pekerjaan responden sebagian besar adalah menjadi buruh tani yaitu sebanyak 22 orang atau sebesar 47,8\%. Sebagian besar responden memiliki pendapatan kurang dari UMR kabupaten Pasuruan yaitu sebesar Rp. 3. 037.500,00 per bulan dengan persentase responden sebanyak $97,8 \%$ dari total keseluruhan.
Dilihat dari tipe kusta yang diderita responden sebagian besar responden mengidap kusta tipe Multi Basiler (MB) dengan jumlah 43 orang atau sebesar $93,5 \%$ dari total keseluruhan responden. Sebagian besar responden memiliki kartu jaminan kesehatan dan memanfaatkan kartu jaminan kesehatan tersebut yaitu sejumlah 32 orang atau $69,6 \%$ dari total keseluruhan. Responden terbanyak tidak mengikuti kelompok perawatan diri yaitu sebanyak 25 orang atau sebesar $54,6 \%$. Hanya setengah dari responden yang mengikuti kelompok perawatan diri.

\section{Dukungan Keluarga Responden}

Berikut adalah data yang diperoleh mengenai dukungan keluarga responden secara ke seluruah mencakup 4 komponen dukungan keluarga yaitu dukungan pengharapan, dukungan nyata, dukungan informasi dan dukungan emosional.

Tabel 2. Distribusi Responden Berdasarkan Dukungan Keluarga di Wilayah Kerja Puskesmas Grati Kabupaten Pasuruan Tahun 2016

\begin{tabular}{lcc}
\hline \multicolumn{1}{r}{ Kategori } & Jumlah & \% \\
\hline Baik & 7 & 15,3 \\
Cukup & 8 & 39,1 \\
Kurang & 21 & 45,6 \\
\hline Total & 46 & 100 \\
\hline
\end{tabular}

Kategori baik pada dukungan keluarga ini didapatkan apabila responden memiliki skor lebih dari 48, dikategorikan cukup apabila skor 36-48 dan kurang jika skor kurang dari 36 dengan skor total keseluruhan yaitu 64. Kuesioner meliputi 4 komponen dukungan keluarga yang masing-masing berisi 4 pertanyaan untuk masing-masing komponen dukungan.

Setiap komponen dukungan terdiri dari 4 pertanyaan yang dinilai dengan skala likert. Komponen dukungan pengharapan, dukungan nyata, dukungan informasi dan 
dukungan emosional dikategorikan baik yaitu responden memiliki skor lebih dari 12, cukup jika skor 9-12 dan kurang apabila skor kurang dari 9 dari skor keseluruhan yaitu 16.

Tabel 3. Distribusi Responden Berdasarkan 4 Komponen Dukungan Keluarga di Wilayah Kerja Puskesmas Grati Kabupaten Pasuruan Tahun 2016

\begin{tabular}{lcc}
\hline \multicolumn{1}{c}{ Kategori } & Jumlah & \% \\
\hline Dukungan Pengharapan & \\
Baik & 2 & 4,3 \\
Cukup & 26 & 56,6 \\
Kurang & 18 & 39,1 \\
\hline Total & 46 & 100 \\
\hline Dukungan Nyata & & \\
Baik & 13 & 28,2 \\
Cukup & 11 & 24 \\
Kurang & 22 & 47,8 \\
\hline Total & 46 & 100 \\
\hline Dukungan Informasi & & \\
Baik & 3 & 6,5 \\
Cukup & 16 & 34,8 \\
Kurang & 27 & 58,7 \\
\hline Total & 46 & 100 \\
\hline Dukungan Emosional & & \\
Baik & 20 & 43,4 \\
Cukup & 18 & 39,2 \\
Kurang & 8 & 17,4 \\
\hline Total & 46 & 100 \\
\hline
\end{tabular}

\section{Pengetahuan Responden tentang Perawatan Diri}

Berikut ini hasil yang diperoleh dari kuesioner mengenai pengetahuan responden tentang perawatan diri:

Pengetahuan responden dikatakan baik yaitu responden mampu menjawab 13-16 pertanyaan dengan benar. Kategori cukup yaitu responden mampu menjawab 9-12 pertanyaan dengan benar sedangkan kategori kurang berarti responden hanya
Tabel 4. Distribusi Responden Berdasarkan Pengetahuan tentang Perawatan Diri di Wilayah Kerja Puskesmas Grati Kabupaten Pasuruan Tahun 2016

\begin{tabular}{lcc}
\hline \multicolumn{1}{c}{ Kategori } & Jumlah & \% \\
\hline Baik & 4 & 8,7 \\
Cukup & 16 & 34,8 \\
Kurang & 26 & 56,5 \\
\hline Total & 46 & 100 \\
\hline
\end{tabular}

bisa menjawab $0-8$ pertanyaan saja dari totsl keseluruhan pertanyaan yaitu 16 soal.

\section{Perawatan Diri Responden}

Perawatan diri responden dikatakan baik jika responden melakukan perawatan diri lebih dari $75 \%$ dari seluruh rangkaian perawatan dirinya. Dikatakan cukup apabila responden mampu melakukan perawatan diri $56-75 \%$ dari rangkaian perawatan diri yang seharusnya dilakukan. Dikategorikan kurang apabila responden hanya melakukan perawatan diri kurang dari 56\% dari keseluruhan rangkaian perawatan diri yang harus dilakukan.

\section{Hubungan Dukungan Keluarga dengan Perawatan Diri Responden}

Berdasarkan tabel 6 didapatkan nilai $p$ value $<0,05$ dengan tingkat kepercayaan 95\%. Hal itu menunjukkan ada hubungan antara dukungan keluarga dengan perawatan

Tabel 5. Distribusi Responden Berdasarkan Tindakan Perawatan Diri di Wilayah Kerja Puskesmas Grati Kabupaten Pasuruan Tahun 2016

\begin{tabular}{lll}
\hline Kategori & Jumlah & $\mathbf{\%}$ \\
\hline Baik & 8 & 19,7 \\
Cukup & 9 & 17,3 \\
Kurang & 29 & 63 \\
\hline Total & 46 & 100 \\
\hline
\end{tabular}


Tabel 6. Hubungan Dukungan Keluarga dengan Perawatan diri Responden di Wilayah Kerja Puskesmas Grati Kabupaten Pasuruan Tahun 2016

\begin{tabular}{|c|c|c|c|c|c|c|c|c|c|c|}
\hline \multirow{3}{*}{ Dukungan Keluarga } & \multicolumn{6}{|c|}{ Perawatan Diri } & \multirow{2}{*}{\multicolumn{2}{|c|}{ Total }} & \multirow{3}{*}{ p value } & \multirow{3}{*}{$\begin{array}{c}\text { Koefisien } \\
\text { Korelasi }\end{array}$} \\
\hline & \multicolumn{2}{|c|}{ Baik } & \multicolumn{2}{|c|}{ Cukup } & \multicolumn{2}{|c|}{ Kurang } & & & & \\
\hline & $\mathrm{n}$ & $\%$ & n & $\%$ & n & $\%$ & Jumlah & $\%$ & & \\
\hline Baik & 6 & 13,1 & 0 & 0 & 1 & 2,1 & 7 & 15,2 & 0,00 & 0,690 \\
\hline Cukup & 1 & 2,2 & 9 & 19,6 & 8 & 17,4 & 18 & 39,2 & & \\
\hline Kurang & 1 & 2,1 & 0 & 0 & 20 & 43,4 & 21 & 45,6 & & \\
\hline
\end{tabular}

Tabel 7. Hubungan Pengetahuan Dengan Perawatan Diri Responden di Wilayah Kerja Puskesmas Grati Kabupaten Pasuruan Tahun 2016

\begin{tabular}{|c|c|c|c|c|c|c|c|c|c|c|}
\hline \multirow{3}{*}{ Pengetahuan } & \multicolumn{6}{|c|}{ Perawatan Diri } & \multirow{2}{*}{\multicolumn{2}{|c|}{ Total }} & \multirow{3}{*}{$\begin{array}{c}\mathbf{p} \\
\text { value }\end{array}$} & \multirow{3}{*}{$\begin{array}{r}\text { Koefisien } \\
\text { Korelasi }\end{array}$} \\
\hline & \multicolumn{2}{|c|}{ Baik } & \multicolumn{2}{|c|}{ Cukup } & \multicolumn{2}{|c|}{ Kurang } & & & & \\
\hline & $\mathbf{n}$ & $\%$ & $\mathrm{n}$ & $\%$ & $\mathbf{N}$ & $\%$ & Jumlah & $\%$ & & \\
\hline Baik & 4 & 8,7 & 0 & 0 & 0 & 0 & 4 & 8,7 & 0,00 & 0,691 \\
\hline Cukup & 2 & 4,3 & 9 & 19,5 & 5 & 10,9 & 16 & 34,8 & & \\
\hline Kurang & 2 & 4,3 & 0 & 0 & 24 & 52,2 & 26 & 56,5 & & \\
\hline
\end{tabular}

diri responden. Koefisien korelasi didapatkan sebesar 0,690 yang artinya kekuatan hubungan yang dimiliki adalah kuat.

\section{Hubungan Pengetahuan dengan Perawatan Diri Responden}

Berdasarkan tabel 7 didapatkan $p$ value $<0,05$ dengan tingkat kepercayaan $95 \%$. Hal itu menunjukkan ada hubungan antara pengetahuan dengan perawatan diri responden. Koefisien korelasi didapatkan sebesar 0,691 yang artinya kekuatan hubungan yang dimiliki kuat.

\section{PEMBAHASAN}

\section{Gambaran Karakteristik Responden}

Berdasarkan hasil penelitian diketahui bahwa usia responden terbanyak berada pada rentang 46-55 tahun yang merupakan kategori kelompok usia lansia awal. Saat menginjak usia lansia tubuh akan mengalami prosen penuaan di mana pada proses ini jaringan akan sedikit demi sedikit kehilangan kemampuannya untuk meregenerasi diri dan mempertahankan fungsi normal jaringan sehingga rentan terhadap infeksi penyakit dan sedikit-demi sedikit kehilangan fungsinya untuk memperbaiki kerusakan pada jaringan (Keliat, 2011). Hal ini tidak sejalan dengan Depkes RI (2007) yang menyatakan bahwa penyakit kusta bisa menyerang semua kelompok umur, dengan penderita terbanyak kelompok usia produktif. Perbedaan ini terjadi karena responden yang diambil adalah penderita kusta yang masih memerlukan perawatan diri, bukan penderita kusta secara keseluruhan. Pada usia produktif fungsi jaringan untuk memperbaiki diri cenderung lebih baik daripada lansia. Oleh karena itu kelompok usia lansia masih memerlukan perawatan diri.

Responden pada penelitian ini antara perempuan dan laki-laki memiliki proporsi yang hampir sama. Hal ini sesuai dengan teori yang dikemukakan Harahap (2000), bahwa penyakit kusta dapat menyerang siapa saja baik laki-laki maupun perempuan. $63 \%$ responden dalam penelitian ini tidak pernah bersekolah. Menurut Notoatmodjo (2012), pendidikan merupakan salah 
satu faktor penentu tingkat pengetahuan seseorang. Apabila pengetahuan seseorang tentang suatu penyakit tinggi maka individu akan berupaya dalam kesembuhan dirinya maupun terhadap upaya pencegahan suatu penyakit terhadap dirinya. Sehingga dalam tingkat pendidikan sangat penting kaitannya dengan terjadinya suatu penyakit maupun proses penyembuhan suatu penyakit. Hal ini sejalan dengan penelitian yang dilakukan oleh Tamsuri (2010) yang menyatakan bahwa terdapat hubungan yang signifikan antara pengetahuan dengan pencegahan penyakit kusta dengan $p$ value 0,00 dan koefisien korelasi 0,616 .

$47,8 \%$ responden dalam penelitian ini memiliki mata pencaharian sebagai buruh tani dengan pendapatan keluarga kurang dari UMR kabupaten pasuruan yaitu sebesar Rp.3.037.500,00. Pendapatan merupakan salah satu tolak ukur dalam kesanggupan individu atau keluarga dalam memperoleh pelayanan kesehatan (Notoatmodjo, 2007). Individu dengan pendapatan yang tinggi akan dengan mudah mampu memenuhi kebutuhannya dalam memperoleh pelayanan kesehatan yang memadai untuk dirinya, sebaliknya orang dengan pendapatan kurang akan lebih sulit memenuhi kebutuhan akan pelayanan kesehatan yang memadai.

Responden pada penelitian ini hampir seluruhnya memiliki tipe kusta MB. Kusta tipe MB cenderung lebih banyak menimbulkan kecacatan daripada tipe PB karena memiliki penyebaran basil lebih cepat. Hal ini sejalan dengan penelitian yang dilakukan oleh Witama (2014) yang menyatakan bahwa penderita kusta dengan tipe MB lebih banyak menderita cacat tingkat 2 dari pada tipe PB. Penelitian ini didukung pula oleh penelitian yang dilakukan oleh Ogbeiwi (2005) yang menyatakan bahwa terdapat hubungan antara tipe kusta dengan kecacatan yang dialami oleh penderita kusta. hal inilah yang menyebabkan responden sebagian besar adalah penderita kusta tipe MB karena perawan diri dibutuhkan oleh penderita dengan kecacatan.
Berdasarkan status kepemilikan BPJS diketahui bahwa belum seluruh responden memiliki kartu jaminan kesehatan. 4,3\% responden sudah memiliki kartu BPJS namun ada yang tidak memanfaatkannya dengan alasan perbedaan pelayan yang diberikan. Jaminan kesehatan nasional memiliki fungsi yang salah satunya adalah menjamin ketersediaan pelayanan dalam upaya preventif serta promotif (Kemenkes, 2014). Kepemilikan jaminan kesehatan ini diharapkan dapat meningkatkan derajat kesehatan masyarakat dengan terjaminnya pelayanan kesehatan bagi masyarakat yang memilikinya. Pada penelitian ini responden sebagian besar memiliki kartu jaminan kesehatan. Hal ini dapat disebabkan karena walaupun responden memiliki jaminan kesehatan tetapi pemanfaatan fasilitas kesehatan yang mereka lakukan kurang. Responden belum sepenuhnya memanfaatkan kartu jaminan kesehatan. Hal ini sejalan dengan penelitian yang dilakukan oleh Littik (2008) yang menyatakan bahwa walaupun masyarakat memiliki kartu jaminan kesehatan namun masyarakat enggan memanfaatkan fasilitas kesehatan, hal ini dikarenakan kurangnya pengetahuan masyarakat tentang dampak kesehatan yang diakibatkan oleh suatu penyakit.

Berdasarkan hasil penelitian didapatkan bahwa $54,4 \%$ responden tidak mengikuti kelompok perawatan diri. Puskesmas grati memiliki 2 kelompok perawatan diri yang berada di 2 desa yaitu Desa Rebalas dan Desa Plososari. Kelompok perawatan diri ini merupakan program Puskesmas Grati untuk pencegahan kecacatan penderita kusta. Menurut penelitian yang dilakukan oleh Eldiansyah, dkk (2016) diperoleh hasil bahwa penderita kusta yang aktif mengikuti kelompok perawatan diri memiliki tingkat kecacatan yang lebih rendah daripada penderita kusta yang tidak aktif mengikuti kelompok perawatan diri. Penelitian lain yang dilakukan oleh Wulandari, dkk (2013) menyebutkan bahwa pelatihan perawatan diri pada kelompok perawatan diri efektif 
dalam meningkatkan dukungan emosional dan dukungan instrumental keluarga. Oleh karena itu sangat penting bagi penderita kusta untuk mengikuti kelompok perawatan diri.

\section{Dukungan Keluarga Responden}

Komponen dukungan keluarga dalam penelitian ini meliputi dukungan Pengharapan, dukungan nyata, dukungan Informasional dan dukungan emosional. Berdasarkan hasil penelitian tentang dukungan keluarga diketahui bahwa sebagian besar dukungan keluarga responden kurang. Dukungan keluarga responden apabila dilihat dari ke empat komponen dukungan keluarga diketahui bahwa dukungan informasi responden merupakan komponen dukungan yang memiliki persentase dengan kategori kurang yang paling tinggi dibandingkan komponen dukungan lainnya. Menurut Friedman (2010) keluarga berperan sebagai penyedia informasi serta pencari informasi. Aspek dukungan informasi yang masih kurang adalah dalam hal pencarian informasi oleh keluarga dari berbagai sumber seperti media cetak maupun online.

Keluarga responden hanya mendapatkan informasi dari petugas kesehatan saja. Kurangnya dukungan informasi respondan juga disebabkan karena keluarga tidak mengetahui kondisi responden yang sebenarnya, bahkan keluarga tidak mengetahui tentang penyakit yang diderita oleh responden sehingga tidak ada upaya pencarian informasi oleh keluarga sehubungan dengan penyakit responden. Kemungkinan lain yang menjadi penyebab kurangnya dukungan informasi responden adalah penyakit kusta apabila penderita belum mengalami cacat tingkat 2 maka kondisi penderita kusta secara fisik sama seperti orang normal pada umumnya, sehingga keluarga menganggap responden dalam kondisi sehat.

\section{Pengetahuan Responden tentang Perawatan Diri}

Tingkat pengetahuan responden dalam penelitian ini dibagi menjadi 3 kategori yaitu baik, cukup dan kurang. Berdasarkan hasil penelitian didapatkan bahwa 56,sebagian besar responden memiliki pengetahuan yang kurang tentang perawatan diri. Kurangnya pengetahuan responden kemungkinan disebabkan oleh faktor pendidikan yang rendah, dukungan informasional keluarga yang kurang serta kurangnya partisipasi responden dalam kelompok perawatan diri. Berdasarkan hasil penelitian diketahui bahwa responden dengan pengetahuan yang kurang sebagian besar tidak mengikuti kelompok perawatan diri. Hal ini sejalan dengan pendapat Notoatmodjo (2012), yang menyatakan bahwa faktor-faktor yang memengaruhi pengetahuan seseorang diantaranya adalah pendidikan, informasi, pekerjaan, sosial budaya dan ekonomi, lingkungan, pengalaman serta usia.

Kelompok perawatan diri merupakan wadah bagi penderita kusta ataupun mantan penderita kusta yang dibentuk untuk meningkatkan kemandirian para anggotanya dalam perawatan diri maupun dalam menjalani aktivitas sehari-harinya (Pribadi, 2013). Kegiatan yang dilakukan dalam kelompok perawatan diri meliputi pengobatan, penyuluhan, serta pelatihan perawatan diri. Penyuluhan dan pelatihan yang dilakukan dalam kelompok perawatan diri dapat memberikan wawasan baru bagi penderita kusta mengenai kondisi mereka sehingga diharapkan pengetahuan penderita kusta akan bertambah.

\section{Perawatan Diri Responden}

Perawatan diri responden dalam penelitian ini sebagian besar masih kurang. Tindakan perawatan diri responden yang kurang kemungkinan responden tidak mengikuti kelompok perawatan diri. 
Kelompok perawatan diri merupakan wadah yang baik untuk meningkatkan tindakan perawatan diri penderita kusta karena dalam kelompok perawatan diri para anggota akan saling bertukar pengalaman yang dialami sehingga pengetahuan para anggota akan semakin bertambah (Depkes RI, 2004).

\section{Hubungan Dukungan Keluarga dengan Perawatan Diri Responden}

Berdasarkan uji korelasi pearson yang dilakukan, didapatkan $p$ value sebesar 0,00 dengan tingkat kepercayaan $95 \%$ dan nilai koefisien korelasi sebesar 0,690 . Hal ini menunjukkan bahwa ada hubungan antara dukungan keluarga dengan perawatan diri responden dengan kekuatan hubungan kuat. Menurut Mubarok (2006) keluarga merupakan anggota dalam suatu rumah tangga yang memiliki hubungan darah, hasil adopsi maupun perkawinan (Laili, 2017). Keluarga merupakan unit terkecil sekaligus terdekat bagi individu yang memiliki fungsi memberikan dukungan dalam proses penyembuhan seseorang, tak terkecuali bagi penderita kusta. Hal ini sejalan dengan penelitian Susanto (2013) yang menyatakan bahwa keluarga adalah kelompok yang dapat menyebabkan suatu permasalahan kesehatan namun juga sebagai pemberi solusi atas suatu permasalahan kesehatan.

Menurut Friedman (2010), dukungan keluarga merupakan suatu bentuk hubungan interpersonal yang terdiri dari sikap, tindakan dan penerimaan terhadap anggota keluarga sehingga tercipta kondisi di mana setiap anggota keluarga merasa diperhatikan. Dukungan keluarga dibagi menjadi 4 komponen yaitu dukungan pengharapan, dukungan nyata, dukungan informasi dan dukungan emosional. Berdasarkan hasil penelitian diketahui bahwa dukungan keluarga memiliki andil yang signifikan dalam perawatan diri penderita kusta. Semakin baik dukungan keluarga yang dimiliki oleh responden berdampak pada semakin baik pula perawatan diri yang dilakukan responden.
Hal ini sejalan dengan teori Maslow (2003) yang menyatakan bahwa keluarga merupakan unit terdekat yang dapat memberikan perawatan sesuai dengan keadaan seseorang. Keluarga sebagai support sistem diharapkan mampu memberikan dukungan penuh dalam upaya perawatan diri penderita kusta dalam wujud dukungan pengharapan, dukungan nyata, dukungan informasi maupun dukungan emosional.

Dukungan keluarga yang adekuat dalam perawatan diri responden akan membantu penderita menaati peraturan yang ditetapkan sehubungan dengan perawatan diri penderita kusta, mulai masalah frekuensi hingga tata cara yang tepat dalam melakukan perawatan diri. Hal ini dikarenakan keluarga adalah orang yang pertama kali dituju oleh penderita kusta untuk mendapat nasehat ataupun pendapat. Adanya dukungan keluarga yang baik maka keluarga akan berperan aktif dalam upaya penyembuhan penderita kusta salah satunya dalam hal mengingatkan jadwal minum obat (Zakiyyah, dkk, 2015).

Hal ini berlaku pula dalam hal perawatan diri yang harus dilakukan oleh penderita kusta. Penelitian ini didukung oleh penelitian yang dilakukan oleh Astutik dan Kiptiyah (2016), penelitian ini memperoleh hasil bahwa penderita kusta yang memiliki dukungan keluarga yang baik cenderung melakukan tindakan perawatan diri dengan tepat dan sesuai kondisinya. Penderita kusta dengan dukungan keluarga yang kurang tidak melakukan perawatan diri secara tepat dan benar. Penelitian lain yang juga mendukung penelitian ini adalah penelitian yang dilakukan oleh Mahanani (2013) tentang hubungan antara dukungan keluarga dengan perawatan diri, dalam penelitian ini didapatkan $p$ value sebesar 0,023 yang artinya terdapat hubungan antara dukungan keluarga dengan perawatan diri penderita kusta.

Proporsi dukungan keluarga terendah dalam penelitian ini terdapat pada komponen dukungan informasi. Dukungan informasi 
adalah dukungan berupa penyediaan informasi, saran, sugesti serta jejaring informasi (Friedman, 2010). Dukungan informasi paling minim yang dimiliki oleh responden berasal dari keluarga yang tidak mencari informasi tambahan dari media lain. Keluarga tersebut hanya bergantung pada informasi yang diberikan oleh petugas. Sayangnya, tidak semua penderita rutin kontak dengan petugas kesehatan. Hal ini mengakibatkan informasi yang didapat keluarga menjadi minim yang berdampak pula pada rendahnya dukungan informasi yang didapatkan responden dari keluarga.

Keluarga merupakan kolektor sekaligus desiminator informasi berupa pemberi saran, nasehat, sugesti serta tempat berkeluh kesah di dalam fungsinya sebagai pemberi dukungan informasional (Astutik dan Kiptiyah, 2016). Jika penderita kusta memperoleh dukungan informasi yang baik maka pengetahuan penderita kusta akan semakin baik sehingga berdampak pada proses penyembuhan mereka, tidak terkecuali perawatan diri penderita kusta. semakin baik pengetahuan penderita kusta semakin baik pula perawatan dirinya. Upaya peningkatan dukungan informasi ini dapat diwujudkan dengan program perawatan diri berbasis keluarga di mana keluarga ikut terlibat pada saat kelompok perawatan diri diselenggarakan sehingga peningkatan pengetahuan tidak hanya terjadi pada penderita kusta namun diharapkan pula terjadi pada keluarga penderita. Berdasarkan penelitian yang dilakukan oleh Kusumadewi (2015) diketahui bahwa pelatihan perawatan diri dengan melibatkan keluarga efektif untuk meningkatkan kemandirian perawatan diri penderita kusta.

\section{Hubungan Pengetahuan dengan Perawatan Diri Responden}

Berdasarkan uji korelasi pearson yang dilakukan didapatkan $p$ value dengan tingkat kepercayaan 95\% sebesar 0,00<0,05 dan nilai koefisien korelasi sebesar 0,691. Hal ini menunjukkan bahwa ada hubungan antara pengetahuan dengan perawatan diri penderita kusta dengan kekuatan hubungan kuat. Pengetahuan merupakan hasil tau dari suatu objek melalui pengindraan baik mata, hidung, telinga maupun alat indra lainnya, namun sebagian besar diperoleh dari indra penglihatan dan pendengaran (Notoatmodjo, 2012).

Berdasarkan hasil penelitian diketahui bahwa 56,5\% pengetahuan responden kurang. Penelitian ini menunjukkan bahwa ada hubungan positif antara pengetahuan dengan perawatan diri, di mana semakin tinggi pengetahuan responden maka semakin baik pula perawatan diri responden dan sebaliknya, semakin rendah pengetahuan responden semakin rendah juga perawatan diri responden. Temuan ini sejalan dengan teori Green (2005) yang menyatakan bahwa pengetahuan merupakan faktor penting dalam perubahan perilaku dan berkorelasi positif terhadap perilaku seseorang. Hal ini dapat disebabkan karena beberapa faktor diantaranya adalah pendidikan responden yang rendah disertai dengan status ekonomi menengah kebawah dan pekerjaan yang hanya sebagai buruh tani mengakibatkan kurangnya akses terhadap informasi serta merupakan suatu faktor minimnya akses terhadap masyarakat. Selain faktor sosial ekonomi, faktor lain yang berperan adalah keaktifan responden dalam mengikuti kelompok perawatan diri serta dukungan informasi yang minim dari keluarga.

Menurut Laoming, dkk (2016) menyatakan bahwa pengetahuan merupakan suatu domain penting dalam pembentukan perilaku seseorang. Orang dengan pengetahuan yang baik cenderung akan lebih bertanggung jawab atas kondisi kesehatannya daripada orang yang memiliki pengetahuan yang kurang tentang suatu permasalahan kesehatan. Seseorang yang memiliki pengetahuan yang kurang terhadap suatu permasalahan kesehatan cenderung akan mengabaikan upaya pencegahan terhadap satu penyakit. Hal ini berlaku pula dalam permasalahan perawatan diri penderita 
kusta. semakin tinggi pengetahuan penderita kusta tentang perawatan diri maka akan bertambah baik pula perawatan diri yang ia lakukan, dan sebaliknya jika penderita kusta tidak memiliki cukup pengetahuan tentang perawatan diri maka tindakan perawatan dirinyapun akan kurang baik. Hal ini sejalan dengan penelitian yang dilakukan oleh Wibowo dkk (2013), mengenai personal hygiene penderita kusta. Pada penelitian tersebut dijelaskan bahwa semakin tinggi pengetahuan penderita kusta maka semakin baik tindakan personal hygiene penderita kusta. penelitian lain menyebutkan bahwa terdapat hubungan yang signifikan antara pengetahuan dan dukungan keluarga dengan koefisien korelasi 0,715 yang artinya terdapat hubungan yang kuat antara pengetahuan dan perawatan diri penderita kusta.

Penelitian ini tidak sejalan dengan penelitian yang dilakukan oleh Astutik dan Kiptiyah (2016) yang memperoleh hasil bahwa tidak ada hubungan antara pengetahuan dengan tindakan perawatan diri eks kusta di panti rehabilitasi dengan $p$ value sebesar $0,10>0,05$. Perbedaan ini disebabkan karena responden yang dipakai memiliki karakteristik yang berbeda serta kondisi responden yang berbeda. Responden yang digunakan dalam penelitian Astutik adalah mantan penderita kusta yang tinggal di panti rehabilitasi, secara otomatis mereka melakukan kebiasaan perawatan diri dan kegiatan yang sama sehingga penderita yang memiliki pengetahuan baik maupun responden yang berpengetahuan kurang akan melakukan kegiatan perawatan diri yang relative sama.

\section{SIMPULAN}

Kesimpulan yang dapat ditarik dalam penelitian ini adalah sebagian besar responden adalah kelompok umur lansia awal dengan persentase sebesar $34,8 \%$, responden berdasarkan jenis kelamin memiliki proporsi yang hampir sama antara laki-laki dan perempuan. Sebagian besar responden tidak pernah mengenyam bangku sekolah yaitu sebesar $63 \%$, sebagian besar responden bermata pencaharian sebagai buruh tani dengan persentase sebesar $47,8 \%$, pendapatan keluarga responden sebagian besar > UMR kabupaten pasuruan yaitu sebesar Rp 3.037.500,00 dengan persentase sebesar $97,8 \%$, sebagian besar responden adalah penderita kusta jenis MB dengan persentase sebesar 93,5\%, sebagian besar responden memiliki kartu jaminan kesehatan dan dipergunakan yaitu dengan persentase sebesar $69,6 \%$, sebagian besar responden tidak mengikuti kelompok perawatan diri dengan persentase $54,5 \%$, sebagian besar responden memiliki dukungan keluarga yang kurang dengan persentase 45,6\%. Komponen dukungan keluarga yang paling rendah yaitu pada komponen dukungan informasi, tingkat pengetahuan responden sebagian besar adalah kurang dengan persentase sebesar $56,5 \%$, perawatan diri responden sebagian besar kurang yaitu sebesar $63 \%$.

Terdapat hubungan antara dukungan keluarga dengan perawatan diri penderita kusta dengan $p$ value $0,00<0,05$ dengan tingkat kepercayaan $95 \%$ dan nilai koefisien korelasi sebesar 0,690 yang artinya terdapat hubungan yang kuat. Terdapat hubungan antara pengetahuan dengan perawatan diri penderita kusta dengan $p$ value $0,00<$ 0,05 dengan tingkat kepercayaan $95 \%$ dan nilai koefisien korelasi sebesar 0,691 yang artinya terdapat hubungan yang kuat antara pengetahuan dan perawatan diri.

Saran yang dapat diberikan kepada dinas kesehatan Kabupaten Pasuruan yaitu meningkatkan media penyuluhan ke puskesmas, meningkatkan advokasi untuk membentuk kelompok perawatan diri baru. Bagi Puskesmas Grati hendaknya melakukan sosialisasi tentang manfaat keikutsertaan kelompok perawatan diri dan melakukan penyuluhan tentang dampak penyakit kusta serta perawatan diri yang tepat. Bagi penderita kusta diharapkan ikut dalam kelompok perawatan diri. Bagi peneliti selanjutnya diharapkan hasil penelitian ini dapat dijadikan reverensi untuk 
menggembangkan penelitian tentang faktor lain yang berhubungan dengan perawatan diri kusta.

\section{DAFTAR PUSTAKA}

Astutik. E., Kiptiyah. N. 2016. Faktor-faktor yang Berhubungan dengan Perilaku Perawatan Diri Eks-Penderita Kusta di Unit Pelaksanaan Teknis Rehabilitasi Sosial Eks-Penderita Kusta Ngaget, Tuban, Jawa Timur. Jurnal Epidemiologi Kesehatan Indonesia. vol 1 No.1 hal: 15-21. http://journal.fkm.ui.ac.id/epid/ article/view/1312 (diakses 23/12/2016 pukul 5.50 WIB)

Depkes RI. 2007. Profil Kesehatan Indonesia 2007, Departemen Kesehatan Republik Indonesia, Jakarta.

Depkes RI. 2012. Buku Pedoman Nasional Pemberantasan Kusta, Jakarta: Direktorat Jenderal Pengendalian Penyakit dan Penyehatan Lingkungan.

Dinkes Kabupaten Pasuruan. 2016. Sistem Informasi dan Pelaporan Program P2 Kusta Provinsi Jawa Timur (2). Sub Bagian Pengendalian Penyakit Menular.

Dinkes Kabupaten Pasuruan. 2015. Profil Kesehatan Kabupaten Pasuruan. Departemen Kesehatan Kabupaten Pasuruan.

Eldiansyah, E., Wantiah., Siswoyo. 2016. Perbedaan Tingkat Kecacatan Klien Kusta yang Aktif dan tidak Aktif Mengikuti Kegiatan Kelompok Perawatan Diri (KPD) di Kabupaten Jember. Jurnal Pustaka Kesehatan. Vol. 4 No. 2. Hal: 286-292. jurnal.unej.ac.id/index.php/ JPK/article/download/3204/2549

Friedman, M. 2010. Keperawatan Keluarga, Teori dan Praktik. Jakarta: EGC.

Green,W.L. and Kreuter, M. 2005. Health Program Planning an Educational and Ecological Approadh Fourth Edition. New York: McGrew-Hill Companies.

Harahap, M. 2000. Ilmu Penyakit Kulit, Jakarta: Hipokrates.

Keliat, B. 2011. Keperawatan Kesehatan Jiwa Komunitas. EGC, Jakarta.
Kemenkes RI. 2014. Profil Kesehatan Indonesia 2014, Departemen Kesehatan Republik Indonesia, Jakarta.

Kemenkes RI. 2014. Peraturan Menteri Kesehatan RI Nomor 28 Tahun 2014 tentang pedoman Pelaksanaan Program Jaminan Kesehatan Nasional.

Kemenkes RI. 2015. Ifodatin Kusta 2015, Departemen Kesehatan Republik Indonesia, Jakarta.

Kusumadewi, C. 2015. Efektivitas Pendampingan Perawatan Diri Berbasis Keluarga terhadap Kemandirian Perawatan Diri Penderita Cacat Kusta. Skripsi. UNNES. http://lib.unnes. ac.id/20406/1/6411410097-S.pdf

Lameshow, S., Hosmer, D.W., Klar, J., Lwanga, S.K. 1997. Besar Sampel dalam Penelitian Kesehatan. Yogyakarta: Gadjah Mada University Press.

Laoming, K., Umbah, J., Kepel, B. 2016. Faktor-Faktor yang Berhubungan dengan Kecacatan Pada Penderita Kusta di Kabupaten Bolaang Mongondow. Jurnal Kesehatan Masyarakat. Vol. 4, No. 2. Hal 101-114.www.ejournalhealth.com/index. php/paradigma/article/view/30 (diakses 22/12/2016 pukul 15.00 WIB)

Laili, A.F.N. 2017. Hubungan Akses Pelayanan Kesehatan, Dukungan Keluarga dan Pengetahuan Penderita Kusta dengan Perawatan Diri Penderita Kusta (Studi di Puskesmas Grati Kabupaten Pasuruan Tahun 2016. Skripsi. Universitas Airlangga.

Littik, S., 2008. Hubungan Antara Kepemilikan Asuransi Kesehatan dan Akses Pelayanan Kesehatan di Nusa Tenggara Timur. Jurnal Magiter Kesehatan Masyarakat. Vol. 3 No. 1 hal: 52-61. https://mediakesehatanmasyarakat.files. wordpress.com/2012/06/jurnal-7.pdf

Mahanani. 2013. Faktor-faktor yang Berhubungan dengan Perawatan Diri Kusta pada Penderita Kusta di Puskesmas Kunduran Kecamatan Kunduran Kabupaten Blora. Skripsi. Universitas Negeri Semarang. 
Maslow, A. 2003. Motivasi dan Kepribadian. Jakarta: Midas Surya Grafindo.

Mubarok. 2006. Buku Ajar Keperawatan Komunitas 2. Jakarta: CV Sagung Seto.

Notoatmodjo, S. 2012. Promosi kesehatan dan Perilaku Kesehatan. Jakarta: Rineka Cipta.

Ogbeiwi, O1,. 2005. Progress towards the Elimination of Leprosy in Nigeria: a review of the role of policy Implementation and operational factors. Leprosy Review, Volume 76 (1): 65-76.

Pribadi, DW. Perbedaan Aktivitas Perawatan Diri Klien Kusta yang Aktif dan Tidak Aktif Mengikuti Kelompok Perawatan Diri di Kabupaten Jember. Jember: Skripsi. Lembaga Penelitian Universitas Jember; 2013.

Setiadi. 2008. Keperawatan Keluarga. Jakarta: EGC.

Soedarjatmi.S., Istiarti.T., Widagdo, L. 2009. Faktor-faktor yang Melatarbelakangi Persepsi Penderita terhadap Stigma Penyakit Kusta. Jurnal Promosi Kesehatan Indonesia. Vol4 no 1. Hal. 18-24. E-journal.undip.ac.id/index.php/JPKI/ article/view/2409/2134

Solikhah. A, 2016. Hubungan Tingkat Pengetahuan tentang Kusta (Leprosy) dengan Perawatan Diri Pada Penderita Kusta di Wilayah Kabupaten Sukoharjo. Skripsi. Universitas Muhammadiyah Surakarta. http://eprints.ums . ac.id/42362/

Susanto, N. 2006. Faktor-Faktor yang Berhubungan dengan Tingkat Kecacatan Penderita Kusta, Tesis. Universitas Gadjah Mada.

Tamsuri, A. 2010. Hubungan Pengetahuan dengan Perilaku Pencegahan Penularan
Penyakit Kusta di Wilayah Kerja Puskesmas Tanjunganom.

Kabupaten Nganjuk. Jurnal AKP Vol 1 No 1 Hal: 8-12. http://ejournal.akperpamenang. ac.id/index.php/akp/article/view/5/2 (diakses pada 25/12/2016 pukul 15.00 WIB)

WHO. 2016. Global Leprocy Update 2015: Time for action, accountability and Inclusion no. 35. Hal. 405-420. Apps. who.int/iris/bitsream/10665/249601/1/ WER9135.pdf.

Witama, A. 2014. Karakteristik Penderita Kusta dengan Kecacatan Derajat 2 di RS Kusta Alverno Singkawang Tahun 2010 2013. Skripsi. Universitas Tanjungpura.

Wibowo, E. Semakin Tinggi Pengetahuan Tentang Penyakit Kusta Semakin Baik Perilaku Personal Hygyene Penderita Kusta di Puskesmas Padas. Prosiding Nasional APIKES-AKBID Citra Medika Surakarta.: 99-104. ISBN: 978-60273865-4-9.

Wulandari, L., Suwardani, D., Firmawati, A. 2011. Efektivitas pelatihan perawatan diri terhadap dukungan emosional dan instrumental keluarga penderita kusta. Jurnal Keperawatan Soedirman. Volume 6 No. 2. 62-71.

Jks.fikes.unsoed.ac.id/index.php/jks/ articecle/view/329 (diakses pada 21/12/2016)

Zakiyyah, N., Budiono, I., Zainafree, I. 2015. Faktor-faktor yang berhubungan dengan tingkat kepatuhan minum obat penderita kusta di kabupaten brebes. Jurnal Kesehatan Masyarakat. ISSN 2252-6528. Hal: 58-66. http://journal. unnes.ac.id/sju/index.php/ujph (diakses pada tanggal $25 / 12 / 2016$ pukul 20.30 WIB) 